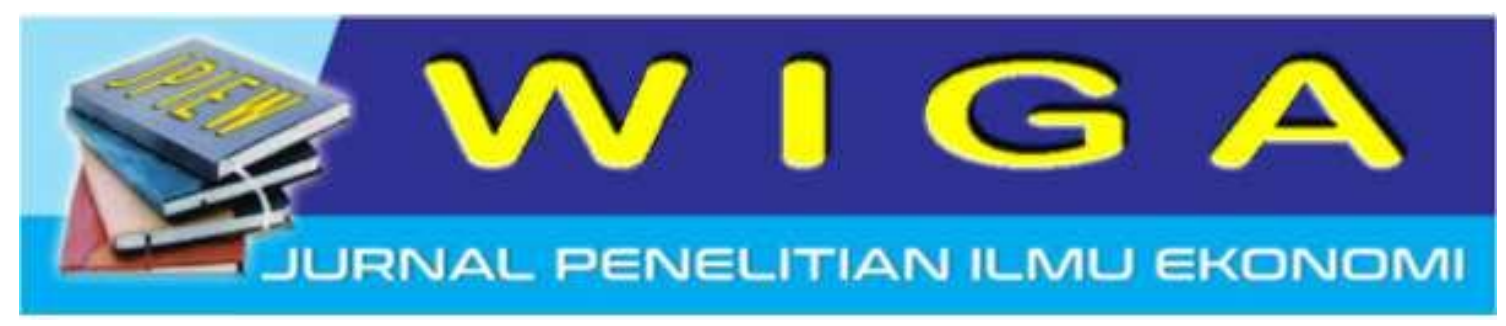

\title{
Pengaruh Motivasi Dan Kepemimpinan Terhadap Kinerja Melalui Perilaku Produktif
}

\author{
Muhdar \\ STIE Mandala Jember \\ email: Yesmuhdar@gmail.com
}

\begin{abstract}
Abstrak
Penelitian ini ditujukan untuk menganalsis pengaruh motivasi dan kepemimpinan terhadap kinerja melalui perilaku produktif studi kasus pada guru PNS di SMK Negeri Kalibaru. Jenis data yang digunakan adalah data primer, diperoleh dengan metode wawancara dan penyebaran kuestioner terhadap populasi seluruh guru Pegawai Negeri Sipil (PNS) di lingkungan SMK Negeri Kalibaru sebanyak 38 orang. Dengan menggunakan analisis regresi diperoleh hasil: (1). Motivasi mempunyai pengaruh yang positif dan signifikan terhadap perilaku produktif, (2). Kepemimpinan mempunyai pengaruh yang posit dan signifikan terhadap kinerja, (3). Motivasi mempunyai pengaruh yang positif dan signifikan terhadap kinerja melalui perilaku produktif, (4). Kepemimpinan mempunyai pengaruh terhadap kinerja guru PNS di SMK Negeri Kalibaru, dan (5). Perilaku produkti mempunyai pengaruh terhadap kinerja guru PNS di SMK Negeri Kalibaru. Dari hasil penelitian diharapkan sekolah dan kepala sekolah lebih memperhatikan dan meningkatkan pelayanan terhadap guru PNS dalam memotivasi dan memimpin guru dan memberikan perilaku yang positif sehingga guru PNS dapat bekerja dengan baik, bertanggung jawab, nyaman dan meningkatkan tujuan sekolah sesuai dengan visi dan misi sekolah.
\end{abstract}

\section{Kata Kunci: Motivasi, Kepemimpinan, dan Kinerja Produktif.}

\section{PENDAHULUAN}

Dengan masuknya MEA, maka kesiapan sumber daya manusia sangat dibutuhkan sebab para pesaing bukan hanya dari negara kita sendiri namun juga dari negara lain akan masuk ke negara Indonesia. Persaingan tersebut dari berbagai aspek baik aspek ekonomi, politik, sosial budaya, ilmu pengetahuan dan teknologi. Dengan daya saing yang semakin hebat pemerintah menggagas program Nawa Cita untuk menuju Indonesia berdaulat secara politik, serta mandiri dalam bidang ekonomi dan kepribadian dalam kebudayaan. Nawa Cita ke lima adalah Meningkatkan kualitas hidup manusia Indonesia melalui peningkatan kualitas pendidikan dan pelatihan dengan program "Indonesia Pintar"; serta peningkatan kesejahteraan masyarakat dengan program "Indonesia Kerja" dan "Indonesia Sejahtera" dengan mendorong land reform dan program kepemilikan tanah seluas 9 hektar, program rumah kampung deret atau rumah susun murah yang disubsidi serta jaminan sosial untuk rakyat di tahun 2019. 
Peningkatan mutu pendidikan diupayakan perbaikan pada kinerja guru dan inovasi selalu dikembangkan sebagimana menurut Rivai (2005:14) kinerja merupakan terjemahan dari kata performance yang didefinisikan sebagai hasil atau tingkat keberhasilan seseorang secara keseluruhan selama periode tertentu untuk melaksanakan tugas dibandingkan dengan berbagai kemungkinan, seperti standar hasil kerja, target atau sasaran atau kriteria yang telah ditentukan terlebih dahulu dan telah disepakati bersama.Pendapat tentang kinerja guru tersebut di atas senada dengan Mangkunegara, Anwar A (2006:67) yang menyatakan bahwa Kinerja (prestasi kerja) adalah hasil kerja secara kualitas dan kuantitas yang dicapai oleh seorang pegawai dalam melaksanakan tugasnya sesuai dengan tanggug jawabyang diberikan kepadanya. Faktor-faktor yang memengaruhi kinerja guru seseorang dapat berasal dari dalam individu itu sendiri seperti motivasi, keterampilan, dan juga pendidikan. Ada juga faktor dari luar individu seperti iklim kerja, tingkat gaji, dan lain sebagainya (Asf \& Mustofa, 2013:160)

Menurut Porter et al., Filak \& Sheldon (Rasheed dkk, 2010), motivasi kerja guru sangat penting bagi kinerja dan keberhasilan dari setiap sistem pendidikan. Menurut penelitian Suryani Dewi Pratiwi (2013) bahwa Motivasi berpengaruh terhadap kinerja guru serta Kepemimpinan Kepala Sekolah menurut persepsi guru berpengaruh terhadap kinerja guru

Persoalan yang dihadapi pada guru dan karyawan di SMK Negeri Kalibaru Banyuwangi tentang motivasi dan kepemimpunan terhadap perilaku produktif yang mempengaruhi kinerja , sebab perilaku produktif sangat diperlukan guna mengukur kinerja guru dan karyawan tersebut terhadap tanggung jawab yang diberikan. Perilaku produktif menjadi faktor penting dalam memberikan kontribusi terhadap kinerja guru PNS pada SMK Negeri Kalibaru, sebab dengan perilaku produktif dapat mengukur seberapa baik guru dan karyawan pada kinerja di sekolah. Disamping perilaku produktif kinerja guru dan karyawan juga dipengaruhi oleh motivasi seorang guru PNS di SMK Negeri Kalibaru. Motivasi kerja harus dapat perhatian yang lebih serius karena dapat mengukur seberapa besar dorongan dari dalam dan luar sekolah. Sebab motivasi yang rendah juga berpengaruh terhadaap perilaku produktif yang rendah pula. Disamping hal tersebut diatas yang tidak kalah pentingnya adalah kepemimpinan seseorang juga diharapkan dapat mempengaruhi kinerja guru PNS di SMK Negeri Kalibaru. rumusan masalah penelitian dapat dirumuskan sebagai berikut : (1) Apakah motivasi berpengaruh terhadap kinerja ?, (2) Apakah kepemimpinan berpengaruh terhadap kinerja ?, (3) Apakah motivasi berpengaruh terhadap kinerja melalui perilaku produktif ?, (4) Apakah kepemimpinan berpengaruh terhadap kinerja melalui perilaku produktif ?, (5) Apakah perilaku produktif berpengaruh terhadap kinerja ?.

\section{TINJAUAN PUSTAKA Motivasi}

Menurut Siagian (1986 : 132) motivasi adalah daya pendorong yang mengakibatkan seorang anggota organisasi mau \& rela untuk mengerahkan kemampuan, dlm bentuk keahlian atau keterampilan, tenaga \& waktunya untuk menyelanggarakan berbagai kegiatan yg menjadi tanggung jawabnya dan menunaikan kewajibannya, dalam rangka pencapaian tujuan \& berbagai sasaran organisasi yg telah ditentukan sebelumnya.

Ada beberapa teori motivasi menurut beberapa ahli diantaranya Teori motivasi menurut Abraham H. Maslow. Bahwa manusia mempunyai hierarki kebutuhan yang dimulai dari jenjang yang paling dasar sampai dengan jenjang yang paling tinggi yaitu a). Kebutuhan fisiologis yaitu secara umum manusia membutuhkan makan dan minum, rumah adapun secara 
organisasi manusia membutuhkan gaji atau upah. b). Kebutuhan rasa aman bahwa manusia membutuhkan kestabilan dalam hidup dan mempersiapkan pasca pensiunan. c). Kebutuhan sosial bahwa manusia membutuhkan rekan kerja yang baik, persahabatan, rasa kasih sayang. d). Kebutuhan harga diri bahwa membutuhkan suatu pengharhaan yaitu berupa jabatan dan status sosial.e). Kebutuhan aktualisasi diri bahwa manusia membutuhkan prestasi dan perkerjaan yang menantang.

Dengan demikian dapat disimpulkan bahwa motivasi kerja guru adalah suatu dorongan kerja bagi guru untuk melaksanakan tugas dan tanggungjawabnya dengan sebaik-baiknya demi mencapai tujuan yang telah ditentukan. Menurut Dimyati dan Mudjiono (2006), motivasi memliki 3 komponen utama yaitu: 1) Kebutuhan, yaitu berkaitan dengan harapann seseorang, 2) Dorongan, yaitu kekuatan untuk memenuhi harapan atau mencapai tujuan, dan 3) Tujuan, yaitu hal yang ingin dicapai yang mengarahkan perilaku atau tindakan.

Faktor-faktor yang mempengaruhi motivasi kerja individu sebagai berikut, ( Yunus , 2007) : a.) Rasa aman, yaitu adanya kepastian untuk memperoleh pekerjaan tetap, memangku jabatan di organisasi selama mungkin seperti yang mereka harapkan. b). Kesempatan untuk maju, yaitu adanya kemungkinan untuk maju, naik tingkat, memperoleh kedudukan dan keahlian. c). Tipe pekerjaan, yaitu adanya perkerjaan yang sesuai dengan latar belakang pendidikan, pengalaman, bakat, dan minat. d). Nama baik tempat bekerja, yaitu perusahaan (sekolah) yang memberikan kebanggaan karyawan bila bekerja di perusahaan atau sekolah tersebut. e). Rekan kerja, yaitu rekan kerja yang sepaham dan cocok untuk kerjasama.

f). Upah, yaitu penghasilan yang diterima. g). Penyelia, yaitu pemimpin atau atasan yang mempuanyai hubungan baik dengan bawahannya, dan mempertimbangkan pendapat-pendapat yang dikemukakan oleh bawahannya. h). Jam kerja, yaitu jam kerja yang teratur atau tertentu dalam sehari. i). Kondisi kerja, yaitu seperti kebersihan tempat kerja, suhu, ruangan kerja, ventilasi, kegaduhan suara, bau, dan sebagainya.

\section{Kepemimpinan}

Menurut Fidler (Amirullah,2015) bahwa pemimpin adalah seorang yang berada dalam kelompok, sebagai pemberi tugas atau sebagai pengarah dan mengkoodinasikan kegiatan kelompok yang relevan, serta dia sebagai penanggung jawab utama.

Menurut Sondang P. Siagan (Amirullah,2015) mengatakan ada lima fungsi-fungsi kepemimpinan yang hakiki yaitu : 1). Fungsi Penentu Arah adalahSetiap organisasi atau perusahaan baik itu organusasi besar, menengah atau kecil yang didirikan pasti mempunyai tujuan. Dalam mencapai tujuan harus menentukan arah baik secara jangka pendek atau jangka panjang. Adapun arah yang dimaksud adalah tertuang dalam strategi dan takti yang telah disusun oeleh pimpinan dalam organisasi. 2). Fungsi Sebagai Juru Bicara adalah Seorang pemimpinan mempunyai peran sebagai penghubung antara organisasi dengan pihak pihak luar yang berkepentingan. 3). Fungsi Sebagai Komunikator adalah Pemimpin dalan hal berfungsi sebagai komunikator yang lebih menekankan pada kemampuan untuk mengkomunikasikan sasar-sasaran, strategi dan tindakan yang harus dilaksanakan oleh bawahan. 4). Fungsi Sebagai Mediator adalah Konfil konflik yang terjadi dan perbedaan perbedaan kepentingan dalam organisasi pasti ada, maka dari dibutuh kehadiran seorang pemimpin yang mampu menjalankan fungsi kepemimpinan selaku mediator yang rasional, obyektif dan netral untuk mennyelasikan masalah adan perbedaan. 5). Fungsi Sebagai Integrator. Kepemimpinan adalah upaya mempengaruhi banyak orang melalui komunikasi untuk mencapai tujuan, cara 
mempengaruhi orang dengan petunjuk atau perintah, tindakan yang menyebabkan orang lain bertindak atau merespon dan menimbulkan perubahan positif, kekuatan dinamis penting yang memotivasi dan mengkoordinasikan organisasi dalam rangka mencapai tujuan, kemampuan untuk menciptakan rasa percaya diri dan dukungan diantara bawahan agar tujuan organisasional dapat tercapai. Namun, semua dari itu adalah penting dan diperlukan untuk memberikan kerangka kerja yang komprehensif bagi para pemimpin sekolah untuk memimpin dan mengelola pendidikan sekolah di abad baru ini, tiga jenis kepemimpinan yang saling melengkapi satu sama lain adalah peningkatan antarmuka internal, akuntabilitas dan masa depan yang relevansi menjadi pertimbangan. Pemimpin sekolah dapat melakukan tidak hanya kepemimpinan internal dan antarmuka, tetapi juga kepemimpinan masa depan, kepemimpinan mereka dapat dianggap sebagai kepemimpinan sekolah total. Kepemimpinan yang baik harus memiliki sifat - sifat, yaitu 1) Mempunyai kemampuan melebihi orang lain. 2) Mempunyai rasa tanggung jawab yang besar. 3) Mau bekerja keras. 4) Pandai bergaul. 5) Memberi contoh bekerja dengan semangat pada bawahan. 6) Memiliki rasa integritas.

\section{Perilaku Produktif}

Perilaku produktif (productive behavior) adalah perilaku pegawai yang berkontribusi positif terhadap tujuan dan sasaran organisasi adapun Perilaku Produktif terdiri dari : 1). Prestasi kerja (job performance), 2). Perilaku kewarganegaraan organisasi (organizational citizenship behavior disingkat $O C B$ ), serta 3). Inovasi dan kreatifitas (Jex dan Britt, 2008).

Perbedaan antara prilaku produktif dan perilaku tidak produktif adalah dari sisi kontribusi terhadap tujuan organisasi. Perilaku produktif akan berkontribusi positif terhadap pencapaian tujuan organisasi, sedangkan perilaku tidak produktif tidak memberikan kontribusi positif terhadap pencapaian tujuan organisasi, bahkan dapat memperlambat atau menghalangi tercapainya tujuan organisasi.Dari pengertian di atas dapat disimpulkan bahwa produktivitas kerja adalah kemampuan karyawan dalam berproduksi dibandingkan dengan input yang digunakan, seorang karyawan dapt dikatakan produktif apabila mampu menghasilkan barang atau jasa sesuai dengan diharapkan dalam waktu yang singkat atau tepat.

\section{Kinerja}

Kinerja adalah hasil atau tingkat keberhasilan seseorang secara keseluruhan selama periode tertentu di dalam melaksanakan tugas dibandingkan dengan berbagai kemungkinan, seperti standar hasil kerja, target atau sasaran atau kriteria yang telah ditentukan terlebih dahulu dan telah disepakati bersama. Akhir ini mengenai kinerja menjadi perbincangan hangat dikalangan para pengambil keputusan baik instansi pemerintah maupun swasta yang selalu menyoroti bagaimana kinerja staf atau karyawannya. Penilaian tentang kinerja individu staf atau karyawan semakin penting ketika suatu organisasi atau lembaga akan melakukan reposisi staf atau karyawan. Artinya bagaimana organisasi/lembaga harus mengetahui faktor-faktor apa saja yang mempengaruhi kinerja, dan apakah masing-masing staf atau karyawan sudah diberi kesempatan untuk mengaktualisasikan diri dalam pekerjaannya? Hasil analisis akan bermanfaat untuk membuat program pengembangan SDM secara optimum.

Dengan demikian, kinerja ditentukan oleh faktor-faktor kemampuan, motivasi dan kesempatan. Kesempatan kinerja adalah tingkat-tingkat kinerja yang tinggi yang sebagian merupakan fungsi dari tiadanya rintangan-ringtangan yang mengendalikan karyawan itu. Meskipun seorang individu mungkin bersedia dan mampu, bisa saja ada rintangan yang menjadi penghambat. Berdasarkan 
pendapat di atas, kinerja adalah kesediaan seseorang atau kelompok orang untuk melakukan sesuatu kegiatan dan menyempurnakannya sesuai dengan tanggung jawabnya dengan hasil seperti yang diharapkan. Pengertian performance atau kinerja adalah hasil kerja yang dapat dicapai oleh seseoarng atau kelompok orang dalam suatu organisasi sesuai dengan wewenang dan tanggung jawab masing-masing dalam upaya pencapaian tujuan organisasi secara legal, tidak melanggar hukum dan tidak bertentangan dengan moral atau etika.

Kinerja adalah hasil kerja yang dapat dicapai oleh seseoarng atau kelompok orang dalam suatu organisasi sesuai dengan wewenang dan tanggung jawab masing-masing dalam upaya pencapaian tujuan organisasi secara legal, tidak melanggar hukum dan tidak bertentangan dengan moral atau etika. Indikator yang digunakan dalam Kinerja menggunakan penilaian dari Buchori Zainudin $(1982 ; 62)$ , yaitu 1). Hubungan harmonis. 2) Kepuasan kerja. 3) Iklim kerja. 4). Kemanfaatan. 5). Kepuasan dalam imbalan. 6). Ketenangan Jiwa.

\section{Kerangka Konseptual}

Penagaruh variabel motivasi dan kepemimpinan terhadap kinerja melalui perilaku produktif dapat dilihat pada kerangka konseptual dibawah ini :

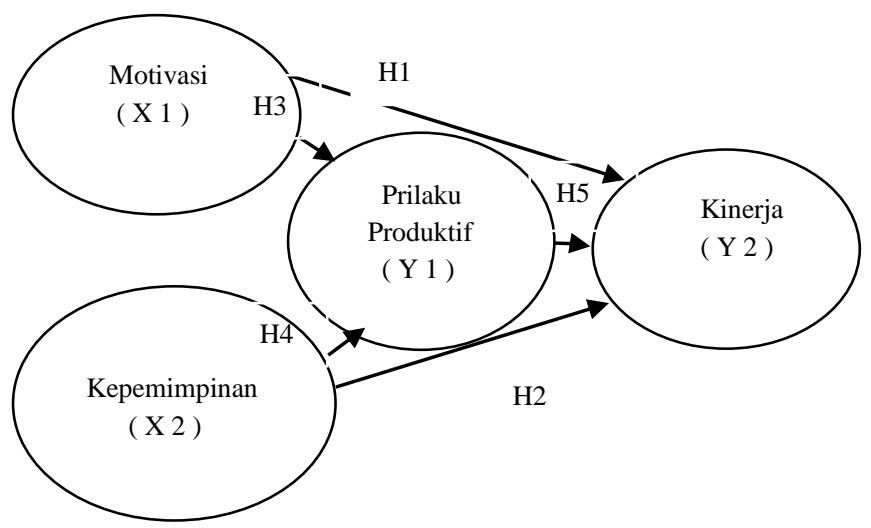

Keterangan :

Hipotesis
Dari permasalah yang dikembangkan maka hipotesis penelitian adalah :

$\mathrm{H} 1$ = Motivasi berpengaruh terhadap kinerja

$\mathrm{H} 2=$ Kepemimpinan berpengaruh terhadap kinerja.

H3= Motivasi berpengaruh terhadap kinerja melalui periliku produktif.

$\mathrm{H} 4=$ Kepemimpinan berpengaruh terhadap kinerja melalui perilaku produktif.

$\mathrm{H} 5=$ Perilaku produktif berpengaruh terhadap kinerja

\section{METODOLOGI DATA}

\section{Ruang Lingkup}

Penelitian ini akan dilaksanakan di

SMKN Kalibaru Banyuwangi, pada semester genap tahun pelajaran 2017/2018. Sedangkan waktu penelitian akan dilaksanakan disesuaikan dengan jadwal pelajaran yang sudah ditetapkan oleh Sekolah.

Populasi dan Sampling Penelitian adalah jika kita hanya akan meneliti sebagian dari populasi, maka penelitian tersebut disebut penelitian sampel. Menurut Sugiyono (2010:215) sampel adalah "sebagian dari populasi itu". Populasi itu misalnya penduduk diwilayah tertentu, jumlah pegawai pada organisasi tertentu, jumlah guru dan murid di sekolah tertentu dan sebagainya. Sampling jenuh adalah sampel yang mewakili jumlah populasi. Biasanya dilakukan jika populasi dianggap kecil atau kurang dari 100.

Populasi dalam penelitian ini adalah semua guru PNS SMK Negeri Kalibaru Banyuwangi yang berjumalah 38 orang sebagai responden dalam penelitian ini. Tehnik pengambilan sampel adalah sampel sensus artinya semua populasi digunakan sebagai sampel.

Menurut Ferdinand (2006), penelitian yang ingin mencari kejelasan dalam bentuk hubungan sebab akibat antara beberapa konsep atau beberapa variabel atau beberapa strategi yang 
dikembangkan dalam manajemen disebut penelitian kausalitas sehingga penelitian ini merupakan penelitian jenis penelitian kausalitas. Sumber data dalam penelitian ini menggunakan data primer dan data sekunder.

Di dalam penelitian ini menggunakan 3 variabel yaitu : a). Variabel independen atau variabel bebas dalam penelitian ini adalah Motivasi ( X1 ) dan Kepemimpinan ( X2 ). B) Variabel dependen atau variabel terikat dalam penelitian ini adalah Kinerja ( Y2 ). c). Sedangkan Variabel intervening dalam penelitian ini adalah perilaku produktif ( Y1).

Berdasarkan identifikasi variabel, maka berikut ini akan dijelaskan definisi operasional variabel penelitian yaitu : 1). Variabel bebas Motivasi ( $X^{I}$ ), Menurut Porter et al., Filak \& Sheldon (Rasheed dkk, 2010), motivasi kerja guru sangat penting bagi kinerja dan keberhasilan dari setiap sistem pendidikan.Motivasi kerja guru adalah dorongan yang menggerakan dan mempengaruhi guru untuk melaksanakan tugas dan tanggungjawabnya dengan baik sesuai dengan tujuan yang telah ditetapkan. Dengan demikian dapat disimpulkan bahwa motivasi kerja guru adalah suatu dorongan kerja bagi guru untuk melaksanakan tugas dan tanggungjawabnya dengan sebaik-baiknya demi mencapai tujuan yang telah ditentukan.Menurut Yunus (2007), faktorfaktor yang mempengaruhi motivasi kerja individu sebagai berikut: a). Rasa aman, yaitu adanya kepastian untuk memperoleh pekerjaan tetap, memangku jabatan di organisasi selama mungkin seperti yang mereka harapkan, b). Kesempatan untuk maju, yaitu adanya kemungkinan untuk maju, naik tingkat, memperoleh kedudukan dan keahlian, c). Tipe pekerjaan, yaitu adanya perkerjaan yang sesuai dengan latar belakang pendidikan, pengalaman, bakat, dan minat, d). Nama baik tempat bekerja, yaitu perusahaan (sekolah) yang memberikan kebanggaan karyawan bila bekerja di perusahaan atau sekolah tersebut, e). Rekan kerja, yaitu rekan kerja yang sepaham dan cocok untuk kerjasama, f). Upah, yaitu penghasilan yang diterima, g).Penyelia, yaitu pemimpin atau atasan yang mempuanyai hubungan baik dengan bawahannya, dan mempertimbangkan pendapat-pendapat yang dikemukakan oleh bawahannya, h). Jam kerja, yaitu jam kerja yang teratur atau tertentu dalam sehari, i). Kondisi kerja, yaitu seperti kebersihan tempat kerja, suhu, ruangan kerja, ventilasi, kegaduhan suara, bau, dan sebagainya. 2). Variabel Kepemimpinan $\left(\mathrm{X}^{2}\right)$. Hersey dan Blanchard berpendapat : " kepemimpinan adalah proses mempengaruhi aktivitas seseorang atau kelompok untuk mencapai tujuan dalam situasi tertentu". Kepemimpinan yang baik harus memiliki sifat - sifat, yaitu : 1) Mempunyai kemampuan melebihi orang lain. 2) Mempunyai rasa tanggung jawab yang besar. 3) Mau bekerja keras. 4) Pandai bergaul. 5) Memberi contoh bekerja dengan semangat pada bawahan. 6). Memiliki rasa integritas. Variabel terikat dalam penelitian ini adalah Kinerja $\left(\mathrm{Y}^{2}\right.$ ) Kinerja adalah hasil kerja yang dapat dicapai oleh seseoarng atau kelompok orang dalam suatu organisasi sesuai dengan wewenang dan tanggung jawab masing-masing dalam upaya pencapaian tujuan organisasi secara legal, tidak melanggar hukum dan tidak bertentangan dengan moral atau etika. Indikator yang digunakan dalam Kinerja menggunakan penilaian dari Buchori Zainudin $(1982 ; 62)$ , yaitu : 1). Hubungan harmonis, 2). Kepuasan kerja, 3). Iklim kerja. 4). Kemanfaatan, 5). Kepuasan dalam imbalan, 6). Ketenangan Jiwa. Variabel intervening dalam penelitian ini adalah perilaku produktif $\left(\mathrm{Y}^{1}\right)$. Perilaku produktif (productive behavior) adalah perilaku pegawai yang berkontribusi positif terhadap tujuan dan sasaran organisasi.Perilaku Produktif terdiri dari; 1). Prestasi kerja (job performance), 2). Perilaku organisasi (organizational 
citizenship behavior disingkat $O C B), 3)$. Inovasi dan kreatifitas (Jex dan Britt, 2008).

\section{Metode Analisa Data}

Uji validitas digunakan untuk mengukur sah atau valid tidaknya suatu kuesioner. Suatu kuesioner dikatakan valid jika pertanyaan pada kuesioner mampu untuk mengungkap sesuatu yang akan diukur oleh kuesioner tersebut (Ghozali,2001). Berdasarkan hasil dari SPSS bahwa variabel motivasi, kepemimpinan, perilaku produktif dan kinerja diketahui hasil pengujian validitas terhadap variabel motivasi dengan 9 item pertanyaan diperoleh nilai signifikasi karena kurang dari $\alpha(0,05)$, sehingga dapat disimpulkan bahwa seluruh item pertanyaan variabel motivasi dinyatakan valid. Pengujian validitas terhadap variabel kepemimpinan dengan 6 item pertanyaan diperoleh nilai signifikasi kurang dari $\alpha$ $(0,05)$, sehingga dapat disimpulkan bahwa seluruh item pertanyaan variabel kepemimpinan dinyatakan valid. Pengujian validitas terhadap variabel kinerja dengan 5 item pertanyaan diperoleh nilai signifikasi kurang dari $\alpha(0,05)$, sehingga dapat disimpulkan bahwa seluruh item pertanyaan variabel kinerja dinyatakan valid. Pengujian validitas terhadap variabel perilaku produktif dengan 4 item pertanyaan diperoleh nilai signifikasi kurang dari $\alpha(0,05)$, sehingga dapat disimpulkan bahwa seluruh item pertanyaan variabel perilaku produktif dinyatakan valid.

Reliabiltas adalah alat untuk mengukur suatu kuesioner yang merupakan indikator dari variabel. Suatu kuesioner dikatakan reliabel atau handal jika jawaban seseorang terhadap terhadap pertanyaan adalah konsisten atau stabil dari waktu ke waktu (Ghozali,2001). Dalam penguji reliabitas menggunakan software SPSS 20 (Statistical Product and Service Soltions), adapun uji reliablitas dapat dilakukan dengan menggunakan koefisien alpha $(\alpha)$ dari cronbach (Umar,2003:96). Berdasarkan hasil SPSS bahwa variabel motivasi, kepemimpinan, prilaku produktif dan kinerja diketahui hasil pengujian reliabilitas terhadap variabel motivasi dengan 9 item pertanyaan diperoleh nilai Koefisien Cronbach's Alpha variabel motivasi sebesar 0,910 lebih besar dari 0,60, sehingga dapat disimpulkan bahwa seluruh item pertanyaan variabel motivasi dinyatakan reliabel. Pengujian reliabilitas terhadap variabel kepemimpinan dengan 6 item pertanyaan diperoleh nilai Koefisien Cronbach's Alpha variabel kepemimpinan sebesar 0,910 lebih besar dari 0,60, sehingga dapat disimpulkan bahwa seluruh item pertanyaan variabel kepemimpinan dinyatakan reliabel. Pengujian reliabilitas terhadap variabel kinerja dengan 5 item pertanyaan diperoleh nilai Koefisien Cronbach's Alpha variabel kinerja sebesar 0,910 lebih besar dari 0,60, sehingga dapat disimpulkan bahwa seluruh item pertanyaan variabel kinerja dinyatakan reliabel. Pengujian reliabilitas terhadap variabel perilaku produktif dengan 4 item pertanyaan diperoleh nilai Koefisien Cronbach's Alpha variabel perilaku produktif sebesar 0,910 lebih besar dari 0,6 , sehingga dapat disimpulkan bahwa seluruh item pertanyaan variabel perilaku produktif dinyatakan reliabel.

Uji Asumsi klasik adalah untuk menguji agar model jalur yang digunakan cukup memadai dengan data yang ada, dalam arti secara statistik adalah BLUE (Best Linear Unbiased Estimator)maka dilakukan verifikasi model. Verifikasi dilakukan dengan uji asumsi klasik. Uji asumsi klasik yang dilakukan adalah; (1) uji normalitas, model regresi yang tepat adalah memiliki distribusi normal atau mendekati normal. Untuk menguji kenormalan distribusi data dalam penelitian ini menggunakan uji normalitas Kolmogorove-Smirnov seperti terlihat pada

One-Sample Kolmogorov-Smirnov Test

\begin{tabular}{|c|c|c|c|c|}
\hline & $\begin{array}{c}\text { Motivas } \\
\text { i }\end{array}$ & $\begin{array}{c}\text { Kepe } \\
\text { mimpi } \\
\text { nan }\end{array}$ & $\begin{array}{c}\text { Perilak } \\
\text { u_Pro } \\
\text { duktif }\end{array}$ & $\begin{array}{c}\text { Ki } \\
\text { ner } \\
\text { ja }\end{array}$ \\
\hline
\end{tabular}




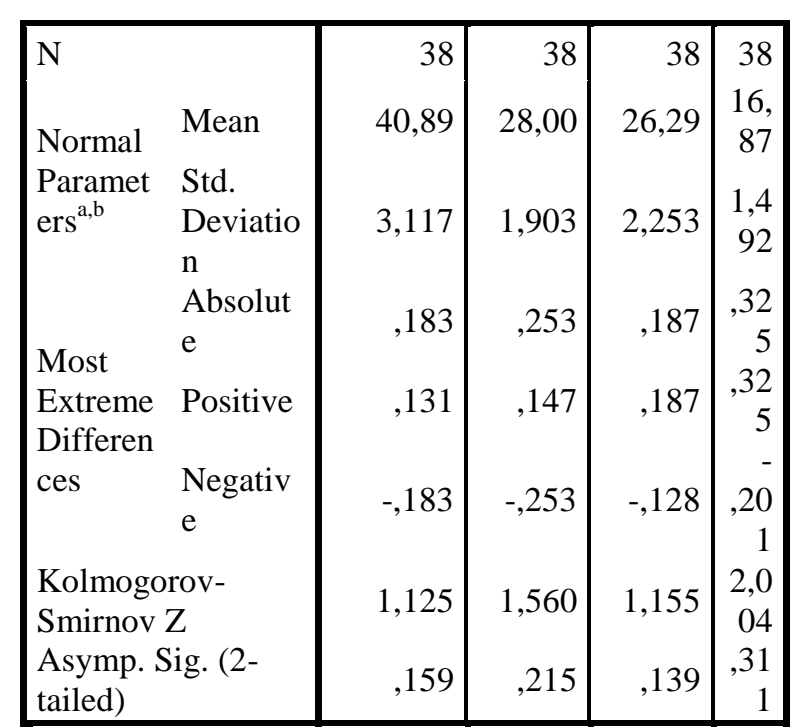

a. Test distribution is Normal.

b. Calculated from data.

Berdasarkan tabel di atas maka distribusi data dalam variabel motivasi signifikannya 0,159 karena lebih besar dari 0,05 maka distribusi datanya normal, untuk distribusi data dalam variabel kepemimpian signifikannya 0,215 karena lebih besar dari 0,05 maka distribusi datanya normal, distribusi data dalam variabel perilaku produktif signifikannya 0,139 karena lebih besar dari 0,05 maka distribusi datanya normal, adapun distribusi data dalam variabel perilaku produksi signifikannya 0,139 karena lebih besar dari 0,05 maka distribusi datanya juga normal.

Uji Multikolinieritas adalah untuk mengetahui hubungan yang sempurna atau hampir sempurna antara variabel-variabel independen, sehingga sulit memisahkan pengaruh tiap-tiap variabel itu secara individu terhadap variabel dependen (Santoso,2000). Pada penelitian ini uji multikolinieritas menggunakan nilai variance inflantion factorrs (VIF) sebagai indikator ada tidaknya multikolinearitas di antara variabel bebas seperti terlihat pada :

coefficients $^{a}$

\begin{tabular}{|cl|r|r|}
\hline \multirow{2}{*}{ Model } & \multicolumn{2}{|c|}{ Collinearity Statistics } \\
\cline { 3 - 4 } & Tolerance & VIF \\
\hline \multicolumn{2}{|c|}{ Motivasi } & .515 & 1,940 \\
& Kepemimpinan & .645 & 1,550 \\
Perilaku_Produktif & .625 & 1,601 \\
\hline \multicolumn{2}{|c|}{ a. Dependent Variable: Kinerja }
\end{tabular}

Dari tabel diatas, diperoleh nilai VIF pada masing-masing variabel yaitu Variabel motivasi ( X1) sebesar 1,940, Variabel kepemimpinan (X2) sebesar 1,550, dan variabel perilaku produktif (Y1) sebesar 1,601. Dikatakan bebas multikolinieritas apabila nila Variance Inflating Factor (VUF) kurang dari 10 atau koefisien korelasi antar variabel bebas dibawah 0,9 (Santoso,2000).

Uji heterokedastisitas dimaksudkan untuk mengetahui apakah varabel residual absolut sama atau tidak sama untuk semua pangamatan. Heteroskedastisitas terjadi jika pada scatterplot titik-titiknya mempunyai pola yang teratur, baik menyempit, melebar maupun bergelombang-gelombang. Persamaan regresi yang baik jika tidak terjadi heteroskedastisitas.

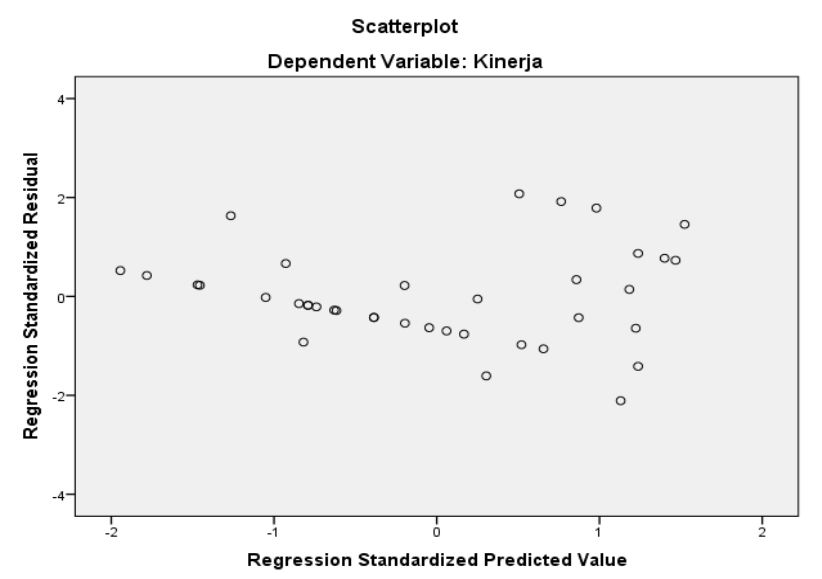

Output Uji Heteroskedastisitas

Berdasarkan scatterplot gambar diatas menunjukkan titik-titik yang menyebar dan tidak mempunyai pola yang teratur, yang mengindikasikan variabel bebas tidak terjadi heteroskedastisitas atau bersifat homoskedastisitas pada semua observasi variabel independent dan varians setiap residual.

Menurut Dimyati (2009). Analisis jalur merupakan regresi yang digunakan untuk menguji kesesuaian (fit) dari matrik korelasi dari dua arah atau lebih yang dibandingkan oleh peneliti. Model ini biasanya digambarkan dengan lingkaran atau anak panah yang menunjukkan hubungan kausalitas. 
Berdasarkan kerangka teori, model analisis jalur yang terbentuk seperti terlihat pada gambar di bawah.

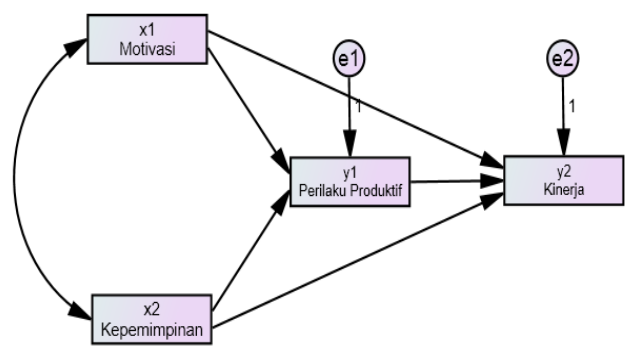

\section{Hasil dan Pembahasan}

Analisis dilakukan dengan menggunakan program SPSS versi-20 dengan tahapan sebagai berikut:

Tahap pertama mengetahui hubungan antar variabel dengan menggunakan nalisis korelasi dan didapatkan output sebagai berikut:

\begin{tabular}{|c|c|c|c|c|c|}
\hline \multicolumn{6}{|c|}{ Correlations } \\
\hline & & Motivasi & $\begin{array}{c}\text { Kepemimpina } \\
n\end{array}$ & $\begin{array}{c}\text { Perilaku_Prod } \\
\text { uktif }\end{array}$ & Kinerja \\
\hline \multirow[t]{3}{*}{ Motivasi } & Pearson Correlation & 1 & $.583^{\prime \prime \prime}$ & .601 & .351 \\
\hline & Sig. (2-tailed) & &, 000 &, 000 &, 030 \\
\hline & N & 38 & 38 & 38 & 38 \\
\hline \multirow[t]{3}{*}{ Kepemimpinan } & Pearson Correlation & $.583^{\prime \prime}$ & 1 & $.448^{\prime \prime \prime}$ &, 038 \\
\hline & Sig. (2-tailed) &, 000 & &, 005 & .820 \\
\hline & N & 38 & 38 & 38 & 38 \\
\hline \multirow[t]{3}{*}{ Perilaku_Produktif } & Pearson Correlation & $601^{11}$ & $.448^{\prime \prime \prime}$ & 1 & $.462^{\prime \prime}$ \\
\hline & Sig. (2-tailed) &, 000 &, 005 & &, 004 \\
\hline & N & 38 & 38 & 38 & 38 \\
\hline \multirow[t]{3}{*}{ Kinerja } & Pearson Correlation & .351 &, 038 & $.462^{\prime \prime \prime}$ & 1 \\
\hline & Sig. (2-tailed) &, 030 &, 820 &, 004 & \\
\hline & N & 38 & 38 & 38 & 38 \\
\hline
\end{tabular}

Pada table diatas correlations, variabel perilaku produktif hubungannya dengan motivasi $(0,000)$ dan kepemimpinan $(0,005)$ menunjukkan adanya hubungan yang signifikan ditunjukkan dengan probabilitas (sig) yang lebih kecil dari $\alpha(0,05)$. Demikian pula dengan variabel kinerja, juga menunjukkan hubungan signifikan dengan variabel motivasi $(0,030)$, kepemimpinan $(0,820)$ dan perilaku produktif $(0,004)$. Selanjutnya melakukan analisis regresi terhadap model jalur substrural 1 dan jalur substrural 2 .

Tahap kedua analisis jalur substrukral 1

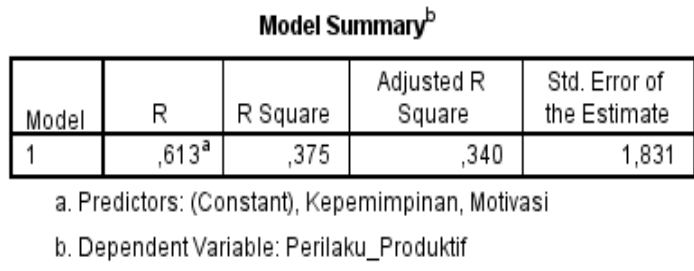

Pada table model summary seperti terlihat di atas, nilai determinasi (Adjusted $R$ Square) adalah 0,340 atau $34 \%$. Nilai tersebut menunjukkan besarnya pengaruh variabel motivasi dan kepemimpinan terhadap perilaku produktif sebesar 37,5\%. Artinya besarnya pengaruh variabel lain (e1) sebesar $100 \%-34 \%=66 \%$.

\begin{tabular}{|c|c|c|c|c|c|c|}
\hline \multicolumn{7}{|c|}{ ANOVA $^{\mathrm{a}}$} \\
\hline \multicolumn{2}{|c|}{ Model } & $\begin{array}{l}\text { Sum of } \\
\text { Squares }\end{array}$ & $d f$ & Mean Square & $\mathrm{F}$ & Sig. \\
\hline \multirow[t]{3}{*}{1} & Regression & 70,502 & 2 & 35,251 & 10,517 &, $000^{12}$ \\
\hline & Residual & 117,314 & 35 & 3,352 & & \\
\hline & Total & 187,816 & 37 & & & \\
\hline
\end{tabular}

Berdasar tabel ANOVA seperti terlihat di atas digunakan untuk menguji pengaruh simultan motivasi dan kepemimpinan terhadap perilaku produktif. Hipotesis yang diuji dirumuskan sebagai berikut: Berdasarkan probabilitas (sig) seperti terlihat pada tabel ANOVA yaitu 0,000 lebih kecil dari $\alpha(0,05)$, maka Ho ditolak. Artinya secara simultan motivasi dan kepemimpinan berpengaruh signifikan terhadap perilaku produktif.

Coefficients $^{\mathrm{a}}$

\begin{tabular}{|c|c|c|c|c|c|c|}
\hline \multirow[b]{2}{*}{ Model } & & \multicolumn{2}{|c|}{ Unstandardized Coefficients } & \multirow{2}{*}{$\begin{array}{c}\begin{array}{c}\text { Standardized } \\
\text { Coefficients }\end{array} \\
\text { Beta }\end{array}$} & \multirow[b]{2}{*}{$t$} & \multirow[b]{2}{*}{ Sig. } \\
\hline & & $B$ & Std. Error & & & \\
\hline \multirow[t]{3}{*}{$\overline{1}$} & (Constant) & 6,187 & 4,746 & & 1,304 & 201 \\
\hline & Motivasi &, 372 &, 119 &, 515 & 3,132 &, 003 \\
\hline & Kepemimpinan &, 174 & 195 &, 147 & 895 & 377 \\
\hline
\end{tabular}

a. DependentVariable: Perilaku_Produktif

Tabel Coefficients di atas menunjukkan besarnya pengaruh variabel motivasi dan kepemimpinan terhadap perilaku produktif masing-masing 0,515 dan 0,147. Pengaruh variabel motivasi terhadap perilaku produktif signifikan, karena probabilitas (sig) lebih kecil dari $\alpha$ $(0,05)$ yaitu 0,003 , dan pengaruh variabel kepemimpinan terhadap perilaku produktif 
tidak signifikan karena probabilitas (sig) kepemimpinan adalah 0,377 lebih besar dari $\alpha(0,05)$.

Tahap ketiga analisis jalur substrukral 2

\begin{tabular}{|c|c|c|c|c|}
\hline Model & R & R Square & $\begin{array}{c}\text { Adjusted R } \\
\text { Square }\end{array}$ & $\begin{array}{c}\text { Std. Error of } \\
\text { the Estimate }\end{array}$ \\
\hline 1 &, $536^{\text {a }}$ &, 287 &, 224 & 1,314 \\
\hline
\end{tabular}
a. Predictors: (Constant), Perilaku_Produktif,
Kepemimpinan, Motivasi
b. Dependent Variable: Kinerja

Pada tabel model summary seperti terlihat di atas, nilai determinasi (Adjusted $R$ Square) adalah 0,224 atau 22,4\%. Nilai tersebut menunjukkan besarnya pengaruh variabel motivasi, kepemimpinan, dan perilaku produktif terhadap kinerja sebesar $22,4 \%$. Artinya besarnya pengaruh variabel lain $(e 2)$ sebesar $100 \%-22,4 \%=$ $77,6 \%$.

\begin{tabular}{|c|c|c|c|c|c|c|}
\hline \multicolumn{7}{|c|}{ ANOVA $^{\mathrm{a}}$} \\
\hline \multicolumn{2}{|c|}{ Model } & $\begin{array}{l}\text { Sum of } \\
\text { Squares }\end{array}$ & df & Mean Square & $\mathrm{F}$ & Sig. \\
\hline \multirow[t]{3}{*}{1} & Regression & 23,637 & 3 & 7,879 & 4,563 & $.009^{b}$ \\
\hline & Residual & 58,705 & 34 & 1,727 & & \\
\hline & Total & 82,342 & 37 & & & \\
\hline
\end{tabular}

a. Dependent Variable: Kinerja

b. Predictors: (Constant), Perilaku_Produktif, Kepemimpinan, Motivasi

Berdasarkan ANOVA seperti terlihat di atas ini digunakan untuk menguji pengaruh simultan motivasi, kepemimpinan, dan perilaku produktif terhadap kinerja. Berdasarkan probabilitas (sig) seperti terlihat pada tabel ANOVA 0,009 yang lebih kecil dari $\alpha(0,05)$, maka Ho ditolak. Artinya secara simultan motivasi, kepemimpinan, dan perilaku produktif berpengaruh signifikan terhadap kinerja.

Coefficients $^{\mathrm{a}}$

\begin{tabular}{|c|c|c|c|c|c|c|}
\hline \multirow[b]{2}{*}{ Model } & & \multicolumn{2}{|c|}{ Unstandardized Coefficients } & \multirow{2}{*}{$\begin{array}{c}\begin{array}{c}\text { Standardized } \\
\text { Coefficients }\end{array} \\
\text { Beta }\end{array}$} & \multirow[b]{2}{*}{ t } & \multirow[b]{2}{*}{ Sig. } \\
\hline & & $B$ & Std. Error & & & \\
\hline \multirow[t]{4}{*}{1} & (Constant) & 10,849 & 3,488 & & 3,110 &, 004 \\
\hline & Motivasi &, 130 & 097 &, 272 & 1,348 & ,187 \\
\hline & Kepemimpinan & -249 &, 141 & -318 & $-1,762$ &, 087 \\
\hline & Perilaku_Produktif & .292 & 121 & .441 & 2,406 &, 022 \\
\hline
\end{tabular}

Tabel Coefficients menunjukkan besarnya pengaruh variabel motivasi, kepemimpinan, dan perilaku produktif terhadap kinerja masing-masing 0,272, -
0,318 dan 0,441. Pengaruh variabel motivasi $(0,187)$ terhadap kinerja tidak signifikan, karena probabilitas (sig) lebih besar dari $\alpha(0,05)$, pengaruh variabel kepemimpinan $(0,087)$ dan perilaku produktif $(0,022)$ terhadap kinerja signifikan karena probabilitas (sig) lebih kecil dari $\alpha(0,05)$ atau $\alpha(0,10)$.

\section{Hasil Analisis Jalur}

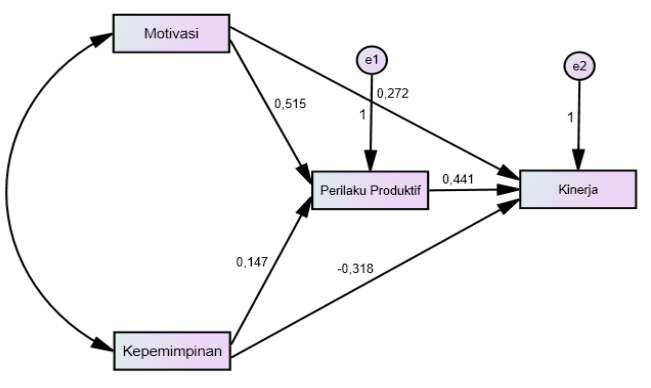

Variabel motivasi memberi pengaruh langsung pada variabel perilaku produktif sebesar 0,515. Hubungan variabel motivasi dengan variabel perilaku produktif sebesar 0,601. Variabel kepemimpinan memberi pengaruh langsung pada variabel perilaku produktif sebesar 0,147. Hubungan variabel kepemimpinan dengan variabel perilaku produktif sebesar 0,449 . Variabel motivasi dan variabel kepemimpinan secara bersamaan memberi pengaruh pada variabel perilaku produktif sebesar 0,375. Pengaruh variabel lain $(e 1)$ terhadap variabel perilaku produktif sebesar 0,625. Variabel motivasi memberi pengaruh langsung pada variabel kinerja sebesar 0,272 . Hubungan variabel motivasi dengan variabel kinerja sebesar 0,351. Variabel kepemimpinan memberi pengaruh langsung pada variabel kinerja sebesar 0,318 . Hubungan variabel kepemimpinan dengan variabel kinerja sebesar 0,038 . Variabel perilaku produktif memberi pengaruh langsung pada variabel kinerja sebesar 0,441 . Hubungan variabel perilaku produktif dengan variabel kinerja sebesar 0,462. Variabel motivasi, kepemimpinandan variabel perilaku produktif secara bersamaan memberi pengaruh pada variabel kinerja sebesar 0,287 . Pengaruh variabel lain $(e 2)$ terhadap 
variabel kinerja sebesar 0,713. Variabel motivasi memberi pengaruh tidak langsung pada variabel kinerja melalui variabel perilaku produktif sebesar $0,515 \mathrm{x}$ $0,441=0,227$, karena lebih kecil dari hubungan langsung dari motivasi terhadap kinerja yaitu 0,272 maka hubungan motivasi lebih kuat secara langsung terhadap kinerja. Variabel kepemimpinan memberi pengaruh tidak langsung pada variabel kinerja melalui variabel perilaku produktif sebesar $0,147 \times 0,441=0,065$, karena lebih besar dari hubungan langsung dari kepemimpinan terhadap kinerja yaitu 0, 318 maka hubungan kepemimpinan lebih kuat secara tidak langsung terhadap kinerja melalui perilaku produktif.

\section{Simpul, Implikasi, Keterbatasan Peneitian dan saran}

Berdasarkan hasil penelitian dan uraian tentang pengaruh motivasi, kepemimpinan melalu perilaku produktif terhadap kinerja guru PNS di SMK Negeri Kalibaru, maka sesuai masing masing hipotesis dapat disimpulkan bahwa : 1). Motivasi berpengaruh terhadap kinerja. 2). Kepemimpinan berpengaruh terhadap kinerja. 3). Motivasi berpengaruh terhadap kinerja melalui perilaku produktif. 4). Kepemimpinan berpengaruh terhadapkinerja melalui perilaku produktif. 5). Perilaku produktif berpengaruh terhadap kinerja. 6). Kepemimpinan melalui perilaku produktif mempunyai pengaruh tidak langsung terhadap kinerja guru PNS di SMK Negeri Kalibaru. Dari analisa data data dan pembahasan dalam penelitian ini, dapat dikemukakan implikasi hasil penelitian bahwa terdapat pengaruh positif yang signifikan antara motivasi, kepemimpinan terhadap perilaku positif yang berdampak terhadap kinerja. Dari kedua variabel bebas dan satu variabel terikat serta satu variabel intervining tersebut telah dikemukakan hipotesis yang membuktikan adanya pengaruh positif yang signifikan antara motivasi, kepemimpinan terhadap perilaku positif yang berdampak terhadap kinerja pada guru PNS di SMK Negeri Kalibaru.
Untuk lebih meningkatkan kinerja dan dapat memberikan perilaku positif terhadap Guru PNS perlu adanya inovasi, kreatifitas dan komunikasi yang baik sehingga perlu adanya fakot faktor lain atau variabel variabel lain.

Karena penelitian ini memiliki keterbatasan yaitu hanya meneliti pengaruh variabel motivasi, kepemimpinan, kinerja serta variabel intervining sedangkan variabel lain tidak diteliti. Untuk peneliti selanjutnya diharapkan dapat melakukan penelitian untuk mengunakan variabel lain yang tidak diteliti dalam penelitian ini. Disamping itu peneliti yang tertarik untuk melakukan penelitian sejenis agar memberikan hasil yang berbeda dengan hasil yang penelitian ini. Penelitian ini hanya dibatasi pada variabel-variabel tertentu yaitu variabel motivasi, kepemimpinan sebagai variabel independen, dan variabel kinerja sebagai variabel dependen sedangkan variabel perilaku produktif sebagai variabel intervening.

Motivasi, kepemimpinan mempunyai pengaruh yang signifikan terhadap kinerja yang melalui perilaku produktif kepada guru PNS di SMK Negeri Kalibaru, maka diharapkan sekolah dan kepala sekolah lebih meningkatkan pelayanan berupa memberikan makan siang dan peralatan pembelajaran yang memadai serta sarana prasana yang layak terhadap guru PNS dalam memotivasi dan memimpin guru dan memberikan perilaku yang positif sehingga guru PNS dapat bekerja dengan baik, bertanggung jawab, nyaman dan dan meningkatkan tujuan sekolah sesuai dengan visi dan misi sekolah.

\section{DAFTAR PUSTAKA}

Amirullah, 2015, Pengantar Manajemen, Mitra Wacana Media, Jakarta.

Agung Prihantoro, 2012, Pengaruh Motivasi, Disiplin, Lingkungan Kerja melalui Komitmen terhadap Kinerja Sumber Daya Manusia, 
Jurnal Value Added, Vol.8,No 2,

Maret 2012-Agustus 2012

Azwar, Saifuddin, 2010. Reliabilitas dan Validitas, Pustaka Belajar, Yogyakarta.

Dharma, Agus, 2003. Manajemen supervisi, Raja Grafindo Persada, Jakarta.

Ghozali, Imam, 2005. Aplikasi analisis Multivariate dengan Program SPSS. Badan Penerbit Universitas Diponegoro.

Hariandja Marihot Tua, Efendi, 2007. Manajemen Sumber Daya Manusia, Penerbit Grasindo, Jakarta.

Hasibuan, Malayu S.P, 2009. Manajemen Sumber Daya Manusia, Edisi Revisi, Bumi Aksara, Jakarta.

Hisbullah Muhib, 2017, Pengaruh Motivasi, Reward dan Lingkungan Kerja terhadap Komitmen serta Dampaknya pada Kinerja,Tesis STIE Mandala Jember.

Istijanto, M. 2010. Riset Sumber Daya Manusia. Jakarta: PT Gramedia Pustaka Utama

Kuncoro, Mudrajat. 2007. Metode Kwantitatif. Yogyakarta : Unit Penerbitan dan Percetakan (UPP) STIP KYPN.

Lako, Adreas. 2004. Kepemimpinan dan kinerja Organisasi : Isu, Teori, dan Solusi. Cetakan Pertama. Penerbit Amara Books, Yogyakarta.

Mangkunegara, Anwar, Prabu. 2009. Evaluasi Kinerja Sumber daya Manusia, PT. Rineka Aditama, Bandung.

Marsuhin, (2016), Pengaruh Kepemimpinan, Kedisiplinan dan
Motivasi terhadap kinerja, Tesis STIE Mandala Jember.

Ni Made Oktaviani ,Ayu Desi Indrawati, 2014, Pengaruh Gaya Kepemimpinan,Kompensasi

Finansial pada Kepuasan Kerja dan Kinerja Karyawan di CV. Wali Sukses Mandiri, Fakultas Ekonomi dan Bisnis Universitas Udayana.

P. Siagian, Sondang, 2004. Teori Motivasi dan Aplikasinya, Rineka Cipta, Jakarta.

Raden Rudi Alhempi ,2012. Pengaruh Kepemimpinan, Kometmen, Motivasi terhadap Kepuasan Kerja, Jurnal Media Riset Bisnis \& manajemen, Vo.12, No. 1, April 2012, pp. 58-80.

Riduwan, 2005. Dasar-Dasar Statistika, CV. Alfabeta, Bandung.

Robbins, Stephen. 2001. Perilaku Organisasi. Jakarta: PT. Prehellindo.

Sugiyono, 2007. Statistika untuk Penelitian, CV. Alfabeta, Bandung.

Suryani Dewi Pratiwi ( 2013 ), Pengaruh Motivasi, Kepuasan Kerja, dan Kepemimpinan, menuturt persepsi guru terhadap kinerja guru, Jurnal Pendidikan Insan Mandiri: Vol.1, No.1 (2013)

Wibowo. 2012. Manajemen Kerja. Yogyakarta. Edisi Ketiga. Jakarta: PT Raja Garafindo Persada

Widagdo, 2017. Manajemen Sumber Daya Manusia, Mandala Press, Jember.

Yuli Suwati , (2013), Pengaruh Kompensasi dan Motivasi Kerja terhadap Kinerja Karyawan Pada PT. Tunas Hijau Samarinda, Journal Ilmu Administrasi Bisnis, Volume 1, nomor 1, 2013:41-55 
WIGA : Jurnal Penelitian IImu Ekonomi, Volume 8 Nomor 2|63 